\title{
Prevalence of obesity, tobacco use, and alcohol consumption by socioeconomic status among six communities in Nicaragua
}

\author{
Timothy S. Laux, ${ }^{1}$ Philip J. Bert, ${ }^{2}$ Marvin González, ${ }^{3}$ Mark Unruh, ${ }^{4}$ \\ Aurora Aragon, ${ }^{3}$ and Cecilia Torres Lacourt ${ }^{3}$
}

Suggested citation Laux TS, Bert PJ, González M, Unruh M, Aragon A, Lacourt CT. Prevalence of obesity, tobacco use, and alcohol consumption by socioeconomic status among six communities in Nicaragua. Rev Panam Salud Publica. 2012;32(3):217-255.

\begin{abstract}
Objective. To describe the prevalence of noncommunicable disease (NCD) risk factors (overweight/obesity, tobacco smoking, and alcohol consumption) and identify correlations between these and sociodemographic characteristics in western and central Nicaragua.

Methods. This was a cross-sectional study of 1355 participants from six communities in Nicaragua conducted in September 2007-July 2009. Demographic and NCD risk-related health behavior information was collected from each individual, and their body mass index (BMI), blood pressure, diabetes status, and renal function were assessed. Data were analyzed using descriptive statistics, bivariate analyses, and (non-stratified and stratified) logistic regression models.

Results. Of the 1355 study participants, $22.0 \%$ were obese and $55.1 \%$ were overweight/ obese. Female sex, higher income, and increasing age were significantly associated with obesity. Among men, lifelong urban living correlated with obesity (Odds Ratio [OR] $=4.39$, 1.18-16.31). Of the total participants, $31.3 \%$ reported ever smoking tobacco and $47.7 \%$ reported ever drinking alcohol. Both tobacco smoking and alcohol consumption were strikingly more common among men $(O R=13.0,8.8-19.3$ and 15.6, 10.7-22.6, respectively) and lifelong urban residents ( $O R=2.42,1.31-4.47$ and 4.10, 2.33-7.21, respectively).

Conclusions. There was a high prevalence of obesity/overweight across all income levels. Women were much more likely to be obese, but men had higher rates of tobacco and alcohol use. The rising prevalence of NCD risk factors among even the poorest subjects suggests that an epidemiologic transition in underway in western and central Nicaragua whereby NCD prevalence is shifting to all segments of society. Raising awareness that health clinics can be used for chronic conditions needs to be priority.
\end{abstract}

Key words Chronic disease; obesity; alcohol drinking; poverty; tobacco smoking; Nicaragua.

Barnes Jewish Hospital, Washington University in St. Louis, St. Louis, Missouri, United States of America. Send correspondence to Timothy S. Laux, e-mail: laux.timothy@gmail.com

2 Universidad Nacional Autónoma de Nicaragua, León, Facultad de Medicina, León, Nicaragua.

3 Centro de Investigación en Salud, Trabajo y Ambiente, Universidad Nacional Autónoma de Nicaragua, León, Nicaragua.

4 Division of Nephrology, University of New Mexico, Albuquerue, New Mexico, United States of America.
Non-communicable diseases (NCDs) are the global leading cause of death. Prevalence continues to rise in developed and developing nations alike. Widespread NCDs, namely cancer, cardiovascular diseases, chronic respiratory diseases, and diabetes account for 35 million deaths per year, $60 \%$ of the annual worldwide total (1).
During the last decade in Latin America, much has been learned about NCDs and their risk factors, yet much remains unknown. Metabolic Syndrome (MS) (2) and risk factors for NCDs are at least as prevalent in parts of Latin America as in developed nations (3). According to one theory, childhood exposure to low-caloric intake predisposes to the de- 
velopment of overweight and obesity later in life if access to hyper-nutrition becomes available. This phenomenon is known as "stunting," and in these settings is generally defined as both short height (women $<150 \mathrm{~cm}$; men $<162 \mathrm{~cm}$ ) and overweight/obesity $(4,5)$. Cigarette smoking (6) and alcohol use (7) are also common in parts of Latin America. Most of the published data on these risk factors focuses on Latin America's upper-middle income nations (8-11) and often, regardless of the economic status of the nation, focuses on pediatric (12), young adult (10), and urban (12-14) populations.

Broad questions remain about NCDs and their associated risk factors among rural populations in Latin America, especially among middle-age adults and the elderly in low and low-middle income nations. For instance, some Latin American rural populations have not been less at-risk for chronic disease than their urban counterparts (10), and unlike in the developed world, where the poorest members of society are often most afflicted by NCDs and their associated risk factors (15), in Latin America there has been no consistent relationship between NCD prevalence and socioeconomic status $(14,16)$.

To the authors' knowledge, there have not been any studies of risk factors in Nicaragua published in English, apart from the World Health Organization's (WHO) Noncommunicable Disease Country Profiles 2011 (17), which provides only a single page of data per country. Among low-middle income countries in Central America, only Guatemala has such a study available in English (5, 12). Responding to this gap, the present study aimed to first, describe the prevalence of overweight/obesity, tobacco smoking, and alcohol consumption among adults in six communities in Nicaragua; and second, to examine any independent correlations between these risk factors and age, sex, medical comorbidities, socioeconomic data, and urban or rural living history.

\section{MATERIALS AND METHODS}

\section{Sample}

Five communities in Nicaragua's northwestern departments of León and Chinandega, and one community in the centrally-located Matagalpa depart- ment were selected-by conveniencebecause they represented five distinct economies: gold mining and subsistence farming; large-scale banana and sugarcane production; small-scale fisheries near the Pacific Ocean; small-scale coffee farming; and the service industry. Five were rural; while one, the service industry community, was in an urban section of the Chinandega department. Coffee farming was the only duplicated economy, however the two communities were located in different departments and were isolated from one another. All of the communities selected had fewer than 800 inhabitants, a size that allows manageable, extensive sampling.

\section{Data collection process}

Data were collected from September 2007-July 2009, with the majority compiled in late 2007-early 2008. All men and women 20-60 years of age in these communities were eligible to participate in this cross-sectional study (no other exclusion criteria). Trained university medical personnel with community representatives performed a census in each community to accurately quantify the size of the total (and study-eligible) population while simultaneously completing the interviews.

The study was approved by the Bioethics Committee of Universidad Nacional Autónoma de Nicaragua in León (UNAN-León). All participants signed a written consent for study procedures.

Potential participants were contacted at their homes and, if amenable to study participation, were interviewed there; if not at home, they were revisited once or twice toward the end of data collection period.

\section{Study instrument}

The questionnaire was administered by trained university staff to each individual. Each interview took approximately 45 minutes, literacy not being an issue since the staff read the questions aloud and recorded the responses. The questionnaire covered demographic information, lifestyle, diseases, and medications to establish the prevalence of the various noncommunicable disease risk factors outlined in the Conjunto de Acciones para la Reducción Multifactorial de Enfermedades No transmisibles (CARMEN) published by the Pan American Health Organization (PAHO) (18).

\section{Measurements and samples}

Within 2 weeks of the interview, participants came to a centrally-located mobile laboratory for the following measurements/tests: blood pressure; height and weight; urinalysis; and blood sample or capillary finger-stick.

Blood pressure was measured using a calibrated M7 sphygmomanometer (Omron Healthcare Inc., Kyoto, Japan) after 5 minutes of quiet, seated rest.

Weight and height were recorded barefoot using a calibrated clinical weight scale and measuring tape, respectively.

Participants provided a random urine sample $(50 \mathrm{~mL})$ in a sterile collector. Two study personnel independently tested each urine sample for glucosuria (glucose levels $\geq 100 \mathrm{mg} / \mathrm{dL}$ ) and three degrees of proteinuria (none = negative - trace; $\mathrm{mi}$ croalbuminuria $=30[+]-100[++] \mathrm{mg} / \mathrm{dL}$; macroalbuminuria $\geq 300[+++$ or ++++$]$ $\mathrm{mg} / \mathrm{dL}$ ) using Bayer's Multistix 10SG urine dipsticks (Bayer AG, Leverkusen, Germany; sensitivity 97\%, specificity 62\%) (19).

Participants in the departments of León and Chinandega provided a blood sample that was stored at $-20^{\circ} \mathrm{C}$ at UNAN-León and transported to the Centro Nacional de Diagnóstico y Referencia, Managua, Nicaragua (National Diagnostic and Reference Center, Managua, Nicaragua) where creatinine was measured using the compensated Jaffe method. In the more remote Matagalpa department, where blood samples could not be adequately refrigerated and delivered to the laboratory, creatinine levels were measured with a capillary finger-stick using a portable StatSensor ${ }^{\mathrm{TM}}$ device (Nova Biomedical Corp., Waltham, Massachusetts, United States; sensitivity 59\%, specificity $88 \%$ ) (20). The glomerular filtration rate (GFR) of each participant was calculated using the Modification of Diet in Renal Disease (MDRD) equation (21). GFR was used to characterize each participant's kidney function by chronic kidney disease (CKD) stage (22).

\section{Study definitions}

Overweight was defined as body mass index (BMI) of $25-30 \mathrm{~kg} / \mathrm{m}^{2}$; obesity was defined as a $B M I \geq 30 \mathrm{~kg} / \mathrm{m}^{2}$. Stunting 
was defined as a height for women $\leq 150$ $\mathrm{cm}$, and for men $\leq 162 \mathrm{~cm} \mathrm{(5).}$

Hypertension was defined as either systolic blood pressure $\geq 140 \mathrm{mmHg}$, diastolic pressure $\geq 90 \mathrm{mmHg}$, or selfreported medical history with diagnosis by a health care professional.

Diabetes mellitus was defined as glucosuria (glucose excretion $\geq 100 \mathrm{mg} / \mathrm{dL}$ ) or self-reported medical history of diabetes mellitus diagnosed by a health care professional. Glucosuria has been previously validated for diabetes screening (23).

Household incomes were categorized into extreme poverty (<US\$1/dependent/ day); poverty (US\$ 1-2/dependent/ day); and not impoverished (> US\$ 2/ dependent/day) according to pre-2008 classifications by the World Bank, after which extreme poverty was adjusted to $<$ US\$ 1.25/dependent/day (24). The prior definitions were employed because collection of the study data was begun before 2008. Although Nicaragua does maintain a national poverty line (25), it does not use the absolute poverty data above. The World Bank classification system was used to allow for international comparisons.

Education was classified both as a dichotomous and continuous variable. Study participants were classified as ever attending school, and if so, average total years of schooling.

Personal health habits included a history of ever smoking tobacco, ever drinking alcohol, ever smoking marijuana, ever using cocaine/crack, or drinking coffee.

Tobacco smoking was quantified in "pack years" (packs smoked daily per years of smoking), assuming a pack-size of 20 cigarettes.

Alcohol consumption was quantified by frequency of use and average amount consumed when drinking, a two-pronged approach used to accurately quantify drinking among both daily drinkers and binge drinkers (common practice among men in Nicaragua). The known percentages of alcohol content for the more popular beverages in Nicaragua were used to calculate past or current average annual consumption of alcohol in grams ( $\mathrm{g}$ ). Conversions included: beer, $8 \mathrm{~g} /$ bottle; chicha or cuzuza, $8 \mathrm{~g}$ /drink; rum, $8.4 \mathrm{~g} /$ drink; and caballito and guaro lija, $9.6 \mathrm{~g} /$ drink.

Marijuana and cocaine/crack use were self-reported by study participants.
Participants were asked if they had ever used any of these substances.

Coffee use was also self-reported as ever drinking coffee, and if so, quantity and frequency.

Residency history included only participants from the five of the six communities (1 088 people), who were asked if they had ever lived in an urban area.

Family history was reported by participants when asked if any relatives had been diagnosed with diabetes, hypertension, and/or renal disease.

\section{Participant followup}

All study participants were given their blood pressure measurements, BMI calculation, and urinalysis results in real time. Any participant with abnormal results was referred to the nearest health clinic. Researchers did not have access to medications, per study protocol. In five of the six communities, GFR results were not immediately available, but following analysis, any participants with CKD Stage III or higher was revisited and advised to seek medical attention promptly.

\section{Statistical analysis}

All data collected were examined using descriptive statistics, including frequency distributions, mean, and standard deviation. Bivariate analyses (chisquared) were conducted to examine the strength of associations between dichotomous independent and dependent variables. Variables demonstrating significance with $P<0.05$, or deemed to be of interest to the outcome based on prior research, were placed into multiple logistic regression models.

Regarding obesity, regression models that controlled for age (stratified by decade), sex, stunting, comorbidities, schooling, poverty, and living history were built and run for all participants. These analyses were also examined after stratifying by sex.

For smoking or alcohol consumption, logistic regression models were performed to adjust for age (stratified by decade), sex, poverty, and living history.

The logistic regression models that adjusted for urban/rural living history and poverty level included 1088 and 824 participants for whom these data were available, respectively. After strati- fication of obese individuals by poverty level, continuous variables were analyzed with analysis of variance (ANOVA).

Statistical analyses were performed using IBM SPSS Statistics software, version 19 (SPSS Inc., an IBM company, Chicago, Illinois, United States).

\section{RESULTS}

Participation rates among the six communities ranged from $76.9 \%-86.2 \%$ of those eligible, with a total study sample of 1355 adults. The demographic characteristics of the study population, organized by BMI classification, are shown in Table 1. Overweight and obesity now affect more than half of Nicaraguans in these six communities, while underweight is comparatively rare, affecting only 1 in 40 individuals.

The factors associated with obesity $\left(\mathrm{BMI} \geq 30.0 \mathrm{~kg} / \mathrm{m}^{2}\right)$ in this study sample are outlined in Table 2, for all participants and by sex. Stunting correlated with obesity in men $(P=0.05)$, but not in women. Compared to women, increasing age was a much larger risk factor for obesity among men, which likely reflects diminishing physical activity over time. The same pattern manifested among men with lifelong urban residency and men who had attended school-both groups were less likely to perform physical labor. Interestingly, schooling did not increase a woman's likelihood of being obese.

Figure 1(a) plots the relationship between income (US\$/dependent/day) and BMI $\left(\mathrm{kg} / \mathrm{m}^{2}\right)$ among study participants providing both data metrics. There was a statistically significant predominance of women with $\mathrm{BMI}>35 \mathrm{~kg} / \mathrm{m}^{2}$ $(P<0.01)$ and $>40 \mathrm{~kg} / \mathrm{m}^{2}(P<0.01)$. Male study participants were wealthier $(P=0.03)$. The trend line in Figure 1(b) demonstrates a small positive correlation between income level and BMI. Despite this overall, small, positive association between income and BMI, which trended towards significance, at BMIs $>35 \mathrm{~kg} / \mathrm{m}^{2}$ and BMIs $>40 \mathrm{~kg} / \mathrm{m}^{2}$ there was no significant difference between income levels. While $52.7 \%$ of the total sample lived in extreme poverty, $53.2 \%$ of those with a BMI $>35 \mathrm{~kg} / \mathrm{m}^{2}$ and $57.1 \%$ of those with a BMI $>40 \mathrm{~kg} / \mathrm{m}^{2}$ lived in extreme poverty.

Table 3 and Figure 2 further delineate who was obese in each poverty category. 
TABLE 1. Attributes of 1355 study participants from six communities, by body mass index (BMI), Nicaragua, 2007-2009

\begin{tabular}{|c|c|c|c|c|c|c|c|c|c|c|c|}
\hline \multirow[b]{3}{*}{ Attribute } & \multicolumn{10}{|c|}{$\mathrm{BMI}\left(\mathrm{kg} / \mathrm{m}^{2}\right)$} & \multirow[b]{3}{*}{$P^{c}$} \\
\hline & \multicolumn{2}{|c|}{ Overall } & \multicolumn{2}{|c|}{$<18.5$} & \multicolumn{2}{|c|}{$18.5-25.0$} & \multicolumn{2}{|c|}{$25.0-30.0$} & \multicolumn{2}{|c|}{$\geq 30.0$} & \\
\hline & No. ${ }^{a}$ & $\%^{b}$ & No. & $\%$ & No. & $\%$ & No. & $\%$ & No. & $\%$ & \\
\hline Total & 1355 & 100 & 33 & 2.4 & 576 & 42.5 & 448 & 33.1 & 298 & 22.0 & $N A^{d}$ \\
\hline \multicolumn{12}{|l|}{ Age (years) } \\
\hline $20-29$ & 543 & 40.1 & 17 & 3.1 & 297 & 54.7 & 158 & 29.1 & 71 & 13.1 & \multirow{4}{*}{$<0.01$} \\
\hline $30-39$ & 379 & 28.0 & 5 & 1.3 & 147 & 38.8 & 124 & 32.7 & 103 & 27.2 & \\
\hline $40-49$ & 272 & 20.1 & 5 & 1.8 & 85 & 31.3 & 101 & 37.1 & 81 & 29.8 & \\
\hline $50-60$ & 161 & 11.9 & 6 & 3.7 & 47 & 29.2 & 65 & 40.4 & 43 & 26.7 & \\
\hline \multicolumn{12}{|l|}{ Sex } \\
\hline Men & 589 & 43.5 & 13 & 2.2 & 324 & 55.0 & 182 & 30.9 & 70 & 11.9 & \multirow{2}{*}{$<0.01$} \\
\hline Women & 766 & 56.5 & 20 & 2.6 & 252 & 32.9 & 266 & 34.7 & 228 & 29.8 & \\
\hline BMI (mean, standard deviation) & 26.5 & 6.2 & 17.3 & 1.0 & 22.4 & 1.6 & 27.3 & 1.5 & 34.6 & 7.7 & NA \\
\hline Stunting & 364 & 26.9 & 6 & 1.6 & 141 & 38.7 & 126 & 34.6 & 91 & 25.0 & 0.15 \\
\hline Hypertension & 298 & 22.0 & 4 & 1.3 & 88 & 29.5 & 101 & 33.9 & 105 & 35.2 & $<0.01$ \\
\hline \multicolumn{12}{|l|}{$\begin{array}{l}\text { Blood pressure (in mmHg, mean, } \\
\text { standard deviation) }\end{array}$} \\
\hline Systolic & 119.7 & 16.0 & 110.6 & 12.0 & 116.5 & 14.9 & 120.5 & 16.7 & 125.5 & 17 & $<0.01$ \\
\hline Diastolic & 73.2 & 10.0 & 69.2 & 10.3 & 71.2 & 9.4 & 73.3 & 9.3 & 77.4 & 10.7 & $<0.01$ \\
\hline Mean arterial pressure & 88.7 & 11.2 & 83.0 & 9.5 & 86.3 & 10.2 & 89.0 & 10.7 & 93.5 & 12.0 & $<0.01$ \\
\hline Diabetes & 40 & 3.0 & 1 & 2.5 & 8 & 20.0 & 18 & 45.0 & 13 & 32.5 & 0.03 \\
\hline \multicolumn{12}{|l|}{ Chronic kidney disease by stage ${ }^{\mathrm{e}}$} \\
\hline No disease & 820 & 63.5 & 19 & 2.3 & 345 & 42.1 & 269 & 32.8 & 187 & 22.8 & \\
\hline$|-| \mid$ & 399 & 30.9 & 11 & 2.8 & 169 & 42.4 & 129 & 32.3 & 90 & 22.6 & 0.29 \\
\hline III-V & 72 & 5.6 & 0 & 0 & 40 & 55.6 & 22 & 30.6 & 10 & 13.9 & \\
\hline Schooling ever & 1086 & 80.0 & 24 & 2.2 & 458 & 42.2 & 358 & 33.0 & 246 & 22.7 & 0.50 \\
\hline Schooling years ${ }^{\mathrm{e}}$ (mean, standard deviation) & 4.6 & 3.9 & 4.6 & 4.5 & 4.5 & 4.0 & 4.4 & 3.6 & 5.1 & 4.1 & 0.09 \\
\hline \multicolumn{12}{|l|}{ Poverty (US $\$ / d /$ day) e, f } \\
\hline$<\$ 1$ & 434 & 52.7 & 11 & 2.5 & 179 & 41.2 & 144 & 33.2 & 100 & 23.0 & \multirow{3}{*}{0.44} \\
\hline$\$ 1-2$ & 270 & 32.8 & 8 & 3.0 & 106 & 39.3 & 90 & 33.3 & 66 & 24.4 & \\
\hline$\geq \$ 2$ & 120 & 14.6 & 4 & 3.3 & 36 & 30.0 & 43 & 35.8 & 37 & 30.8 & \\
\hline \multicolumn{12}{|l|}{ Urban living historye } \\
\hline Always & 120 & 11.0 & 22 & 3.0 & 313 & 42.6 & 227 & 30.9 & 173 & 23.5 & \multirow{3}{*}{0.38} \\
\hline Sometimes & 233 & 21.4 & 8 & 3.4 & 90 & 38.6 & 83 & 35.6 & 52 & 22.3 & \\
\hline Never & 735 & 67.6 & 1 & 0.8 & 51 & 42.5 & 33 & 27.5 & 35 & 29.2 & \\
\hline Tobacco use & 424 & 31.3 & 11 & 2.6 & 223 & 52.6 & 125 & 29.5 & 65 & 15.3 & $<0.01$ \\
\hline Alcohol use & 647 & 47.7 & 13 & 2.0 & 313 & 48.4 & 198 & 30.6 & 123 & 19.0 & $<0.01$ \\
\hline Illicit drug use & 69 & 5.1 & 2 & 2.9 & 40 & 58.0 & 18 & 26.1 & 9 & 13.0 & 0.05 \\
\hline \multicolumn{12}{|l|}{ Family medical history } \\
\hline Hypertension & 609 & 44.9 & 14 & 2.3 & 252 & 41.4 & 197 & 32.3 & 146 & 24.0 & 0.46 \\
\hline Diabetes & 220 & 16.2 & 7 & 3.2 & 72 & 32.7 & 68 & 30.9 & 73 & 33.2 & $<0.01$ \\
\hline Chronic kidney disease ${ }^{\mathrm{e}}$ & 170 & 12.6 & 3 & 1.8 & 68 & 40.0 & 48 & 28.2 & 51 & 30.0 & 0.05 \\
\hline \multicolumn{12}{|c|}{$\begin{array}{l}\text { a Or mean where specified. } \\
\text { b Or standard deviation where specified. } \\
\text { c For categorical variables, } P \text { values calculated using chi-squared bivariate analyses and logistic regressions. For continuous variables, } P \text { values calculated using linear regressions. } \\
\text { d Not applicable. } \\
\text { e These categories have }<1355 \text { participants due to variations in participant responses. Response rates were }>95 \% \text { for presence of CKD, mean schooling, and family history of CKD. Some } \\
\text { participants chose not to answer income questions ( } 824 \text { total responses) and in one of five villages urban residency history was not asked ( } 1088 \text { total responses). } \\
\text { f US } \$ \text { d/day = United States Dollars per dependent per day. These are the World Bank absolute poverty cut-offs from pre-2008 and are not equivalent to Nicaragua's national } 1998 \text { poverty } \\
\text { classification that classified extreme poverty as less than US } \$ 100 / \text { year (US } \$ 0.27 / \text { day) and poverty as less than US } \$ 185 / \text { year (US } \$ 0.50 / \text { day) ( } 25) \text {. }\end{array}$} \\
\hline
\end{tabular}

Figure 2 demonstrates the prevalence of various other risk factors for chronic disease, sorted by poverty level. Only a history of ever consuming alcohol-Figure 2(e)-was significant $(P<0.01)$, with those living in poverty or not impoverished much more likely to have ever consumed alcohol than those in extreme poverty. This was likely confounded by sex since women in the study sample drank less and had lower incomes than men. The prevalence of obesity among women at the lowest income levels trended towards significance-Figure 2(a), $P=0.06$. Figure 2 demonstrates that obesity had a high prevalence at all socioeconomic levels.

The sociodemographic factors associated with ever smoking tobacco or ever drinking alcohol are shown in Table 4, with male sex, increasing age, and urban living all independently correlating with tobacco use and alcohol consumption, particularly male sex. This trend likely reflects who has access to and can afford these products: $57.2 \%$ of the men versus only $11.4 \%$ of the women had ever smoked tobacco; likewise, $80.1 \%$ of men versus only $22.8 \%$ of women had ever consumed alcohol. Figure 3(a) illustrates the relationship between income (in US\$/dependent/day) and total pack years for all former and current smokers (231 study participants) who provided income data. Among smokers, most had smoked < 10 pack years total at all income levels. Note that in Nicaragua, cigarettes are generally sold individually, not by the pack. Figure 3(b) shows a small inverse correlation among smokers between income and total pack years that trended towards significance, 
TABLE 2. Risk factors associated with obesity among all male and female study participants in six communities, Nicaragua, 2007-2009

\begin{tabular}{|c|c|c|c|c|c|c|}
\hline \multirow[b]{2}{*}{ Risk factor } & \multicolumn{6}{|c|}{ Adjusted odds ratios ${ }^{a}$} \\
\hline & Total & $95 \% \mathrm{Cl}^{\mathrm{a}}$ & Males & $95 \% \mathrm{Cl}$ & Females & $95 \% \mathrm{Cl}$ \\
\hline \multicolumn{7}{|l|}{ Age group (years) } \\
\hline 20-29 (referent) & 1 & & & 1 & 1 & \\
\hline $30-39$ & 2.09 & $1.35-3.25$ & 9.28 & $2.88-29.9$ & 1.55 & $0.94-2.55$ \\
\hline $40-49$ & 2.94 & $1.84-4.71$ & 12.6 & $3.98-40.1$ & 2.10 & $1.19-3.70$ \\
\hline $50-60$ & 2.19 & $1.21-3.98$ & 9.63 & $2.53-36.7$ & 1.39 & $0.69-2.82$ \\
\hline Sex (female as referent) & 0.34 & $0.23-0.50$ & $N A^{b}$ & & NA & \\
\hline Stunting & 1.37 & $0.92-2.02$ & 2.23 & $1.01-4.92$ & 1.20 & $0.75-1.92$ \\
\hline Hypertension & 2.21 & $1.50-3.24$ & 2.86 & $1.33-6.14$ & 2.19 & $1.37-3.48$ \\
\hline Diabetes & 0.62 & $0.24-1.62$ & 0.75 & $0.06-10.02$ & 0.64 & $0.23-1.77$ \\
\hline Schooling, ever & 1.71 & $1.05-2.78$ & 3.07 & $1.04-9.07$ & 1.29 & $0.73-2.30$ \\
\hline \multicolumn{7}{|l|}{ Povertyc } \\
\hline$<\$ 1$ (referent) & 1 & & 1 & & 1 & \\
\hline$\$ 1-2$ & 1.05 & $0.72-1.54$ & 2.37 & $1.05-5.36$ & 0.78 & $0.50-1.21$ \\
\hline$\geq \$ 2$ & 1.78 & $1.09-2.90$ & 1.49 & $0.53-4.21$ & 1.98 & $1.09-3.59$ \\
\hline \multicolumn{7}{|l|}{ Urban living history } \\
\hline Always & 1.02 & $0.58-1.81$ & 4.39 & $1.18-16.31$ & 0.77 & $0.40-1.50$ \\
\hline Sometimes & 1.00 & $0.65-1.54$ & 0.65 & $0.27-1.59$ & 1.19 & $0.72-1.99$ \\
\hline Never (referent) & 1 & & 1 & & 1 & \\
\hline
\end{tabular}

a $95 \%$ Confidence Interval.

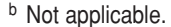

c US\$ per dependent per day.

FIGURE 1. Relationship between income (US\$ /dependent/day) and body mass index (BMI, $\mathrm{kg} / \mathrm{m}^{2}$ ) among 817 study participants in six communities, Nicaragua, 2007-2009

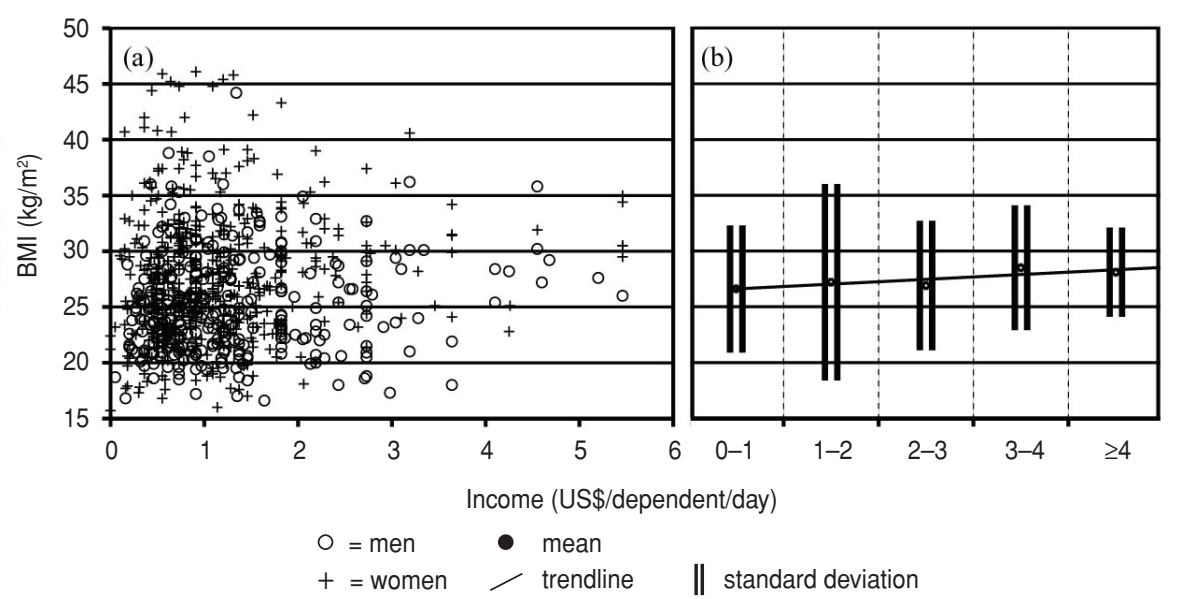

Note: (a) Seven participants for whom this data was available had incomes > US\$6/dependent/day and were excluded (b) Trendline for BMI $\left(\mathrm{kg} / \mathrm{m}^{2}\right)$ at discrete US $\$ 1$ income brackets. Trendline Jonckheere-Terpstra STD J-T statistic $=1.78$ with a two-tailed significance $=0.08(0.07-0.08)$.

evidence that even the poorest smokers can access sufficient tobacco to smoke more frequently than their wealthier smoking counterparts.

Due to variations in the questionnaire, all 267 individuals for whom urban/rural living history was unavailable were from the rural village in the Matagalpa department. A full analyses that included this sixth community's residents coded as "never urban" were also performed, and showed no substantial change from the results presented above. Sensitivity analyses were also performed defining hypertension solely as elevated systolic and/or diastolic reading during study measurement. The results of these analyses did not substantially change the interpretation of the study findings.

\section{DISCUSSION}

The prevalence of overweight/obesity has been rising steadily in Nicaragua. In the 1990s, the overweight/obesity rates were $10 \%-19 \%$ nationwide; by 2000 2004, the prevalence had climbed to $40 \%-49 \%$ (26). The current study closely mirrors the WHO data reported in 2008, $55.5 \%$ overweight, $22.2 \%$ obese (17). It is likely that rates are still trending upward today.

When compared to data collected with similar age inclusion criteria (25-64 years of age) in seven cities located in uppermiddle income countries in Latin America (9), the overall prevalence of obesity in this Nicaraguan sample $(22.0 \%)$ was higher than that of three cities in the other study. However, the prevalence of obesity in men $(11.9 \%)$ was only higher than in one city (Quito, 10.3\%), while the prevalence of obesity in women $(29.8 \%)$ was higher than all but one of the cities (Mexico City, 30.4\%) (9).

Additionally, comparing the prevalence rates of overweight and obesity among this study's sample to that of Central Americans living in California in 2001 (27) is instructive. Though the Californian sample had fairly similar total rates (overweight/obesity, 61.5\%; obesity, $22.2 \%$ ), there are marked differences between the sexes. Among the Central American men living in California, the prevalence of overweight was $50.6 \%$, and of obesity, $17.8 \%$. Among the Central American women living in California, the prevalence of overweight was $28.4 \%$, and that of obesity, $26.5 \%$ (27).

Both of these comparisons-urban, upper-middle income Latin American and Central American immigrants to California-lend further credence to the idea that elevated BMI more greatly affected women in the Nicaraguan sample. This may be explained, in part, by gender roles in rural Nicaragua, where men tend to perform physical labor, often agricultural, and women tend to do work that is less physical. This would also explain why men with lifelong urban residency, where physical labor is less likely, are more obese.

NCDs have transitioned from impacting predominantly the health of society's more affluent members to affecting health across the entire socioeconomic spectrum (28). The majority of deaths in Nicaragua $(69 \%)$ can now be traced 
TABLE 3. Select behaviors and clinical characteristics of obese study participants $(n=203)$ by income level, in six communities, Nicaragua, 2007-2009

\begin{tabular}{|c|c|c|c|c|c|c|c|}
\hline & \multicolumn{6}{|c|}{ Income level } & \multirow[b]{3}{*}{$P^{\mathrm{d}}$} \\
\hline & \multicolumn{2}{|c|}{$<$ US $\$ 1 /$ d/day ${ }^{a}$} & \multicolumn{2}{|c|}{ US\$1-\$2/d/day } & \multicolumn{2}{|c|}{$\geq$ US\$2/d/day } & \\
\hline & Mean $^{b}$ & $\mathrm{SD}^{\mathrm{c}}$ & Mean & SD & Mean & SD & \\
\hline Obese participants (n, \%) & 100 & 49.3 & 66 & 32.5 & 37 & 18.2 & $N A^{e}$ \\
\hline Body mass index $\left(\mathrm{kg} / \mathrm{m}^{2}\right)$ & 34.5 & 5.2 & 35.8 & 13.7 & 33.5 & 4.0 & 0.83 \\
\hline \multicolumn{8}{|l|}{ Blood pressure (mmHg) } \\
\hline Systolic & 127 & 18 & 128 & 18 & 123 & 13 & 0.31 \\
\hline Diastolic & 78 & 10 & 79 & 11 & 78 & 9 & 0.88 \\
\hline Mean arterial pressure & 95 & 13 & 95 & 12 & 93 & 9 & 0.63 \\
\hline Lifetime pack years $^{\dagger}$ & 4.1 & 4.0 & 7.4 & 11.7 & 4.9 & 5.4 & 0.71 \\
\hline Annual alcohol consumption (in grams) ${ }^{g}$ & 10212 & 29780 & 8252 & 18720 & 6103 & 8934 & 0.56 \\
\hline $\begin{array}{l}\text { a United States Dollars per dependent per day. } \\
\text { b Or } n \text { as specified. } \\
\text { c Or percent (\%) as specified. } \\
\text { d Calculated using ANOVA analyses. }\end{array}$ & \multicolumn{6}{|c|}{$\begin{array}{l}\text { e Not applicable. } \\
\text { f Among past and present smokers. } \\
\text { g Among past and present drinkers. }\end{array}$} & \\
\hline
\end{tabular}

FIGURE 2. Among obese (BMI $\geq 30.0 \mathrm{~kg} / \mathrm{m}^{2}$ ) Nicaraguans in six communities, percentage (\%) prevalence of selected characteristics, comorbidities, and noncommunicable disease risk factors by income classification, Nicaragua, 2007-2009
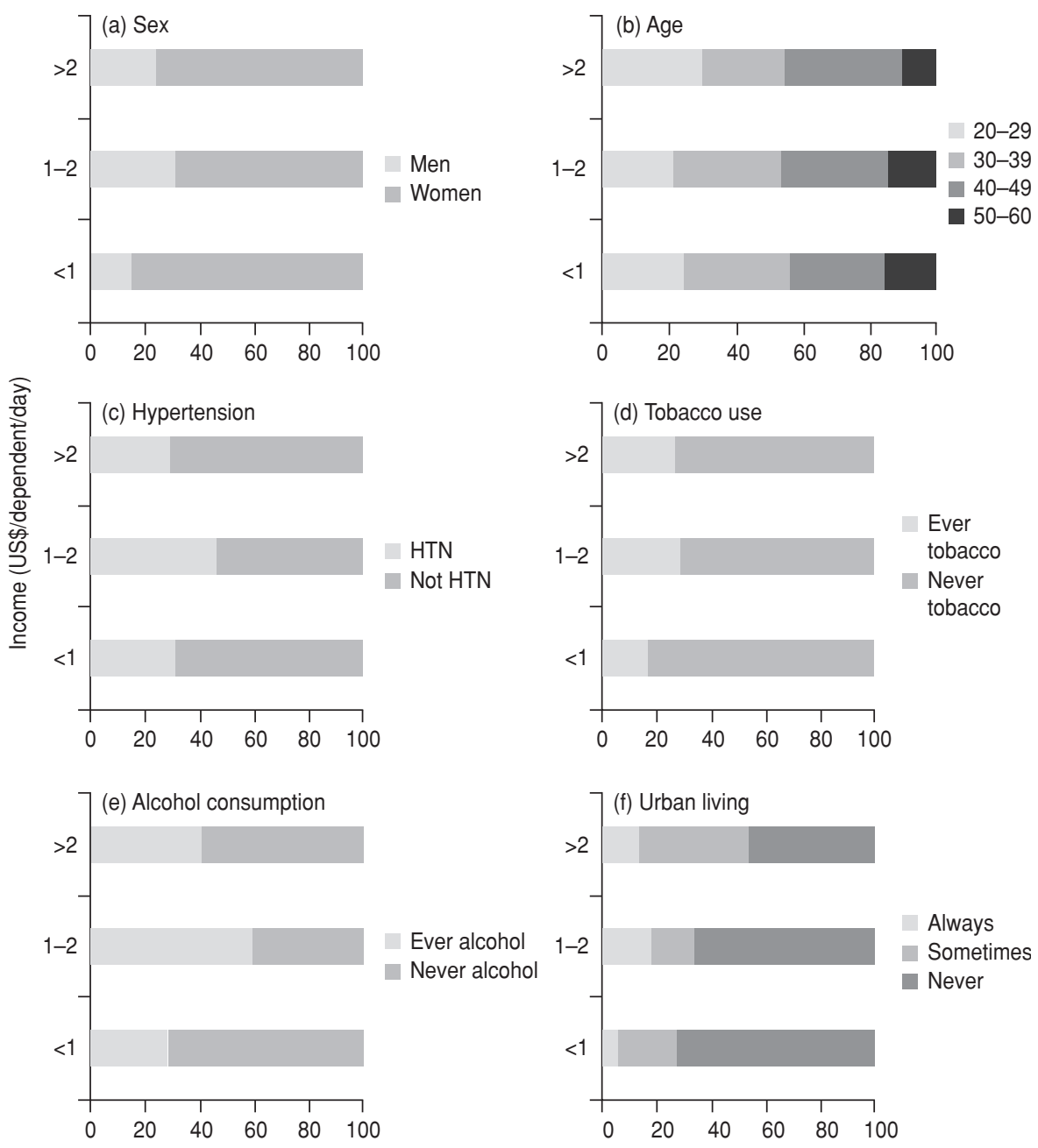

Percentage $(\%)$

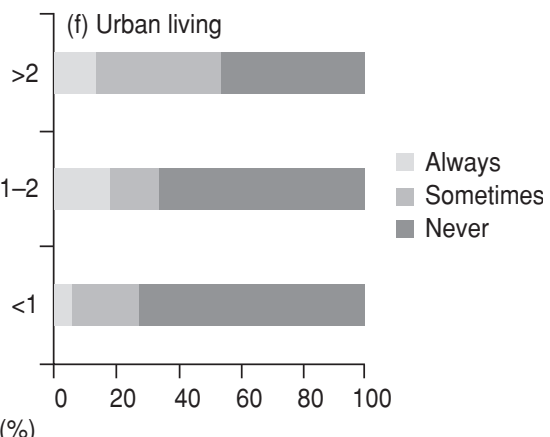

(a) Sex, $P=0.06$

(b) Age, $P=0.89$

(c) Hypertension, $P=0.09$

(d) Ever smoking tobacco, $P=0.11$

(e) Ever consuming alcohol, $P<0.01$

(f) Living in an urban setting, $P=0.10$ to NCDs (17) and the present study clearly demonstrates this trend among NCD risk factors. High BMI is seen at all income levels (Figure 1a), not surprising in a nation where $>95 \%$ of households, both rural and urban, use sugar, salt, and oil six to seven times per week. Nationally, fats and sugar account for approximately one-quarter of all caloric intake $(14.75 \%$ and $11.68 \%$, respectively), with slightly higher rates in urban settings ( $15.08 \%$ and $11.75 \%$, respectively) and slightly lower rates in rural settings (13.93\% and $11.51 \%$, respectively). Only grain remains a larger portion of calories consumed, approximately $40 \%$ of the national total. Oil and salt are used liberally in fried rice and beans, a staple dish in Nicaragua; while sugar is present in high quantities in bottled sodas and is often used excessively to sweeten coffee and other drinks (29).

Among those who smoke tobacco, an inverse relationship exists between lifetime pack years and income status (Figure 3a), though this relationship only trends towards significance. Even though ever trying cigarettes or alcohol is correlated with some history of urban living, both cigarettes and alcohol tend to be sold in small quantities and consumed in binges, especially by men, in rural Nicaragua. As such, even poor, rural Nicaraguans can purchase these items and engage in these unhealthy behaviors regularly.

While most rural Nicaraguans have access to health care services, they are just beginning to use these services for chronic conditions. Many are unaccustomed to seeking care for anything other than acute conditions. In light of changing dietary patterns (29), deaths from chronic NCDs-whether from chronic deterioration or an acute decompensation linked to chronic deterioration from NCD risk factors-will likely increase among adults in rural Nicaragua until its health care facilities are used as frequently for chronic conditions as they are for acute health problems.

The strengths of this study include a high participation rate $(76.9 \%-86.2 \%$ of the eligible adult population in the six communities) and a broad cross-section of Nicaraguan society-both urban and rural from three different departments (Chinandega, León, and Matagalpa) representing five distinct economies. In addition, this study gathered renal health 
TABLE 4. Risk factors associated with history of ever smoking tobacco or ever drinking alcohol in six communities, Nicaragua, 2007-2009

\begin{tabular}{|c|c|c|c|c|}
\hline \multirow[b]{2}{*}{ Risk factor } & \multicolumn{2}{|c|}{ Smoking } & \multicolumn{2}{|c|}{ Drinking alcohol } \\
\hline & $\mathrm{AOR}^{\mathrm{a}}$ & $95 \% \mathrm{Cl}$ & AOR & $95 \% \mathrm{Cl}$ \\
\hline \multicolumn{5}{|l|}{ Age (years) } \\
\hline $20-29$ (referent) & 1 & & 1 & \\
\hline $30-39$ & 1.97 & $1.22-3.18$ & 1.50 & $0.97-2.32$ \\
\hline $40-49$ & 2.91 & $1.80-4.71$ & 2.22 & $1.40-3.51$ \\
\hline $50-60$ & 4.51 & $2.52-8.08$ & 3.93 & $2.25-6.88$ \\
\hline Sex (female as referent) & 13.0 & $8.8-19.3$ & 15.6 & $10.7-22.6$ \\
\hline \multicolumn{5}{|l|}{ Poverty ${ }^{b}$} \\
\hline$<1$ (referent) & 1 & & 1 & \\
\hline $1-2$ & 1.10 & $0.73-1.65$ & 1.16 & $0.79-1.69$ \\
\hline$>2$ & 0.91 & $0.54-1.53$ & 1.20 & $0.72-1.99$ \\
\hline \multicolumn{5}{|l|}{ Urban living history } \\
\hline Always & 2.42 & $1.31-4.47$ & 4.10 & $2.33-7.21$ \\
\hline Sometimes & 1.77 & $1.15-2.74$ & 1.88 & $1.22-2.88$ \\
\hline Never (referent) & 1 & & 1 & \\
\hline
\end{tabular}

a Adjusted Odds Ratios with 95\% Confidence Intervals.

${ }^{\mathrm{b}}$ In United States Dollars/dependent/day.

FIGURE 3. Relationship between income (US\$/dependent/day) and pack years of tobacco smoking among 231 male and female study participants who were past or current smokers, in six communities, Nicaragua, 2007-2009

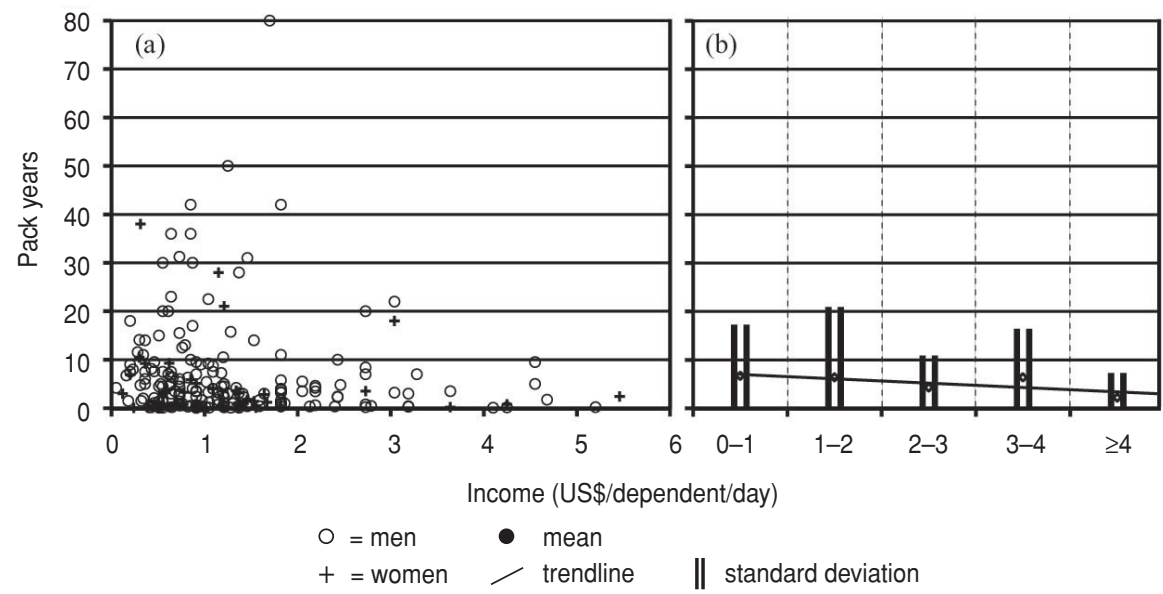

Note: In (b) trendline for pack years at discrete \$1 USD income brackets. Trendline Jonckheere-Terpstra Test STD J-T statistic $=-1.86$ with a two-tailed significance $=0.07(0.06-0.08)$.

data from all participants, allowing the analyses to be controlled for CKD, important for an area where recent research indicates CKD to be a serious health problem (30). Moreover, the study population was screened for other potential confounding comorbidities (i.e., hypertension and diabetes), which allowed these comorbidities to be correlated with the risk factors studied.

\section{Study limitations}

The findings of this study should be interpreted in light of several limitations. Due to logistical constraints, He- moglobin A1c could not be measured, but instead a different diabetes screening technique was used. Neither hip nor waist circumference was measured and fasting blood work was not drawn, meaning neither serum glucose nor triglyceride/cholesterol level was quantified. However, BMI was carefully measured. Blood pressure measurements were only taken at one session for all study participants, though repeated for elevated values after additional seated rest. Previous diagnosis of hypertension was also carefully elucidated with each study participant. Dietary pattern information was not collected from study participants, though other research that has examined these trends in Nicaragua was consulted.

\section{Conclusions}

Of the 1355 Nicaraguans in this community-based study, greater than one-half were overweight or obese, and approximately one-fifth were obese. Obesity was strikingly more prevalent among women; while smoking and alcohol use were much more common among men. Those not living in poverty ( $\geq$ US\$ 2/dependent/day) were more likely to be obese. The prevalence of high BMI (both $>35 \mathrm{~kg} / \mathrm{m}^{2}$ and $>40 \mathrm{~kg} / \mathrm{m}^{2}$ ) insignificantly correlated with poverty level (extreme poverty, poverty, or not impoverished). Those who had lived in urban settings were more likely to have ever smoked tobacco or consumed alcohol, but urban living did not independently correlate with obesity, except in men with lifelong urban residency.

Chronic diseases and their associated risk factors are now well established in the areas of Nicaragua surveyed by this study. This is a concern because, as in most developing countries, the health clinics were generally built to focus on acute health issues (31). While this was once true in Nicaragua, treatment for chronic diseases is now widely available. Public awareness must be raised so that rural populations seek care for chronic health conditions in greater numbers. A possible catalyst for this change might be the training of local health workers focused on NCDs and their associated risk factors. A similar effort is already underway involving midwives in rural Nicaragua.

The development of low-cost, appropriate screening and risk prediction tools that are specific to Nicaragua could both guide the effort of local health workers and allow for longitudinal monitoring of NCD prevalence and risk factors. Further characterization of those NCD risk factors that this study did not assess would be helpful in planning future interventions.

Educational campaigns targeting the dangers of a diet high in fried foods, sodium, and sugar, and among men, binge drinking, would be useful. Finally, regulating food and beverage advertisers and discouraging access to tobacco and alcohol through financial disincentives- 
usually taxation-have been validated in settings similar to Nicaragua's $(32,33)$.

Acknowledgements. Financial support was provided by: the National Institutes of Health (T35 Grant \# 2 T35 DK06552106; Bethesda, Maryland, United States); University of Pittsburgh, School of Medicine, Medical Alumni Association Scholarship (Pittsburgh, Pennsylvania, United States); University of Pittsburgh, Nation- ality Rooms Scholarships (Pittsburgh, Pennsylvania, United States); and the National Center for Research (Resources Grant \# 5UL1 RR024153-05; Bethesda, Maryland, United States).

The authors wish to thank the people of the six communities in the Chinandega, León, and Matagalpa departments for their collaboration in this study.

Conflicts of interest. Mark Unruh has been a consultant to Abbot Laborato- ries (Abbot Park, Illinois, United States), Baxter Healthcare Medical Advisory Board (Deerfield, Illinois, United States), Sigma-Tau Pharmaceuticals (Gaithersburg, Maryland, United States), and UCB S.A. (Brussels, Belgium); however, these consulting roles were not related to any part of the study or manuscript preparation. No equipment or medicine made by the above companies was used at any point in the study.

\section{REFERENCES}

1. World Health Organization. 2008-2013 Action plan for the global strategy for the prevention and control of noncommunicable diseases: prevent and control cardiovascular diseases, cancers, chronic respiratory diseases and diabetes. Available from: http://whqlibdoc. who.int/publications/2009/9789241597418_ eng.pdf Accessed 10 January 2012.

2. Albert KG, Eckel RH, Grundy SM, Zimmet PZ, Cleeman JI, Donato KA, et al. Harmonizing the metabolic syndrome: a joint interim statement of the International Diabetes Federation Task Force on Epidemiology and Prevention; National Heart, Lung, and Blood Institute; American Heart Association; World Heart Federation; International Atherosclerosis Society; and International Association for the Study of Obesity. Circulation. 2009;120(16):1640-5.

3. Escobedo J, Schargrodsky H, Champagne B, Silva H, Boissonnet CP, Vinueza R, et al. Prevalence of the metabolic syndrome in Latin America and its association with subclinical carotid atherosclerosis: the CARMELAcross-sectional study. Cardiovasc Diabetol. 2009;8:52.

4. López-Jaramillo P. Cardiometabolic disease in Latin America: the role of fetal programming in response to maternal malnutrition. Rev Esp Cardiol. 2009;62(6):670-6.

5. Yount KM, Hoddinott J, Stein AD. Disability and self-rated health among older women and men in rural Guatemala: the role of obesity and chronic conditions. Soc Sci Med. 2010;71(8):1418-27.

6. Champagne BM, Sebrié EM, Schargrodsky H, Pramparo P, Boissonnet C, Wilson E. Tobacco smoking in seven Latin American cities: the CARMELA study. Tob Control. 2010;19(6): 457-62.

7. Rehm J, Mather C, Popova S, Thavorncharoensap M, Terrawattananon Y, Patra J. Global burden of disease and injury and economic cost attributable to alcohol use and alcohol-use disorders. Lancet. 2009;373(9682):2223-33.

8. The World Bank. Country and Lending Groups. Available from: http://data.worldbank.org/ about/country-classifications/country-andlending-groups\#Upper_middle_income Accessed 13 January 2012.
9. Schargrodsky H, Hernández-Hernández R, Champagne BM, Silva H, Vinueza R, Silva Aycaguer LC, et al. CARMELA: assessment of cardiovascular risk in seven Latin American cities. Am J Med. 2008;121(1):58-65.

10. Bustos P, da Silva AA, Amigo H, Bettiol H, Barbieri MA. Metabolic syndrome in young adults from two socioeconomic Latin American settings. Nutr Metab Cardiovasc Dis. 2007;17(8):581-9.

11. Medina-Lezama J, Morey-Vargas OL, ZeaDíaz H, Bolaños-Salazar JF, Corrales-Medina F, Cuba-Bustinza C, et al. Prevalence of lifestyle-related cardiovascular risk factors in Peru: the PREVENCION study. Rev Panam Salud Publica. 2008;24(3):169-79.

12. Groeneveld IF, Solomons NW, Doak CM. Nutritional status of urban schoolchildren of high and low socioeconomic status in Quetzaltenango, Guatemala. Rev Panam Salud Publica. 2007;22(3):169-77.

13. Hernández-Hernández R, Silva $H$, Velasco M, Pellegrini F, Macchia A, Escobedo J, et al. Hypertension in seven Latin America cities: the Cardiovascular Risk Factor Multiple Evaluation in Latin America (CARMELA) study. J Hypertens. 2010;28(1): 24-34.

14. Goldstein J, Jacoby E, del Aguila R, López A. Poverty is a predictor of non-communicable disease among adults in Peruvian cities. Prev Med. 2005;41(3-4):800-6.

15. Deaton A. Policy implications of the gradient of health and wealth. Health Aff (Millwood). 2002;21(2):13-30.

16. Fleischer NL, Diez Roux AV, Alazraqui M, Spinelli $\mathrm{H}$. Social patterning of chronic disease risk factors in a Latin American city. J Urban Health. 2008;85(6):923-37.

17. World Health Organization. Noncommunicable diseases country profiles 2011: Nicaragua. Geneva: WHO; 2011. Pp. 139.

18. Organización Panamericana de la Salud. CARMEN: Una iniciativa para Conjunto de Acciones para la Reducción Multifactorial de Enfermedades No transmisibles. Washington, DC: OPS; 2003. Pp. 3-4.

19. Collier G, Greenan MC, Brady JJ, Murray B, Cunningham SK. A study of the relationship between albuminuria, proteinuria, and urinary reagent strips. Ann Clin Biochem. 2009;46(3):247-9.

20. Korpi-Steiner NL, Williamson EE, Karon BS. Comparison of three whole blood creatinine methods for estimation of glomerular filtration rate before radiographic contrast administration. Am J Clin Pathol. 2009;132(6):920-6.

21. Levey AS, Coresh J, Greene T, Steven LA, Zhang YL, Hendriksen S, et al. Using standardized serum creatinine values in the modification of diet in renal disease study equation for estimating glomerular filtration rate. Ann Intern Med. 2006;145(4):247-54.

22. Levey AS, Coresh J, Balk E, Kausz ET, Levin A, Steffes MW, et al. National Kidney Foundation practice guidelines for chronic kidney disease: evaluation, classification, and stratification. Ann Intern Med. 2003;139(2):137-47.

23. Davies MJ, Williams DR, Metcalfe J, Day JL. Community screening for non-insulindependent diabetes mellitus: self-testing for post-prandial glycosuria. Q J Med. 1993;86 (10):677-84.

24. Ravallion M, Shaohua C, Sangraula P. Dollar a Day Revisited. World Bank Econ Rev. 2009; 23(2):163-184.

25. Gobierno de Nicaragua Instituto de Estadísticas y Censos. Perfil y características de los pobres en Nicaragua. Encuesta Nacional de Hogares sobre Medición de Nivel de Vida 1998. Proyetco MECOVI. 2001(Feb):1-91.

26. Rueda-Clausen CF, Silva FA, López-Jaramillo $P$. Epidemic of overweight and obesity in Latin America and the Caribbean. Int J Cardiol. 2008;125(1):111-2.

27. Bowie JV, Juon HS, Cho J, Rodriguez EM. Factors associated with overweight and obesity among Mexican Americans and Central Americans: results from the 2001 California Health Interview Survey. Prev Chronic Dis. 2007;4(1):A10.

28. Biggs B, King L, Basu S, Stuckler D. Is wealthier always healthier? The impact of national income level, inequality, and poverty on public health in Latin America. Soc Sci Med. 2010;71(2):266-73.

29. Organización de las Naciones Unidas para la Alimentación y la Agricultura. Seguridad Alimentaria y Nutricional — Nicaragua. 2004. Available at: www.rlc.fao.org/iniciativa/ 
cursos/Curso\%202006/Mod3/9e.pdf Accessed 8 January 2012.

30. Torres C, Aragón A, González M, López I, Jakobsson K, Elinder CG, et al. Decreased kidney function of unknown cause in Nicaragua: a community based survey. Am J Kidney Dis. 2010;55(3):485-96.

31. Allotey P, Reidpath DD, Yasin S, Chan CK, de-Graft Aikins A. Rethinking health-care systems: a focus on chronicity. Lancet. 2011;377(9764):450-1.

32. Asaria P, Chisholm D, Mathers C, Ezzati M, Beaglehole R. Chronic disease prevention: health effects and financial costs of strategies to reduce salt intake and control tobacco use. Lancet. 2007;370(9604):2044-53.

33. Cecchini M, Sassi F, Lauer JA, Lee YY, Guajardo-Barron V, Chisholm D. Tackling of unhealthy diets, physical inactivity, and obesity: health effects and cost-effectiveness. Lancet. 2010;376(9754):1775-84.

Manuscript received on 4 March 2012. Revised version accepted for publication on 10 June 2012

RESUMEN Objetivo. Describir la prevalencia de los factores de riesgo (sobrepeso/obesidad, tabaquismo y consumo de alcohol) de las enfermedades no transmisibles (ENT), y determinar las correlaciones entre estos y las características sociodemográficas en las

Prevalencia de la obesidad, el tabaquismo y el consumo de alcohol según la condición socioeconómica en seis comunidades de Nicaragua

Palabras clave zonas occidental y central de Nicaragua.

Métodos. De septiembre del 2007 a julio del 2009, se llevó a cabo este estudio transversal en 1355 participantes de seis comunidades de Nicaragua. Para cada persona, se recopiló información demográfica y sobre la conducta en materia de salud relacionada con el riesgo de ENT, y se evaluaron el índice de masa corporal (IMC), la presión arterial, la presencia o no de diabetes y la función renal. Se analizaron los datos mediante estadísticas descriptivas, análisis de dos variables, y modelos de regresión logística (análisis no estratificado y estratificado).

Resultados. De los 1355 participantes en el estudio, 22,0\% eran obesos y 55,1\% presentaban sobrepeso u obesidad. El sexo femenino, los ingresos más altos y la edad más avanzada se asociaron significativamente con la obesidad. En los varones, la residencia de por vida en un entorno urbano se correlacionó con la obesidad (razón de posibilidades $[\mathrm{OR}]=4,39,1,18-16,31$ ). Del total de participantes, 31,3\% habían fumado tabaco y $47,7 \%$ habían consumido alcohol alguna vez. Tanto el tabaquismo como el consumo de alcohol fueron considerablemente más frecuentes en los varones (OR $=13,0,8,8-19,3$ y 15,6, 10,7-22,6, respectivamente) y en los que residían de por vida en un entorno urbano ( $\mathrm{OR}=2,42,1,31-4,47$ y 4,10, 2,33-7,21, respectivamente). Conclusiones. Se observó una alta prevalencia de obesidad/sobrepeso en todos los niveles de ingresos. Las mujeres tenían muchas más probabilidades de ser obesas, pero los varones mostraban mayores tasas de tabaquismo y consumo del alcohol. La creciente prevalencia de los factores de riesgo de las ENT, incluso en las personas más pobres, sugiere que se está produciendo una transición epidemiológica en las zonas occidental y central de Nicaragua mediante la cual la prevalencia de las ENT se está desplazando a todos los segmentos de la sociedad. La concientización de que los dispensarios pueden utilizarse para atender a las afecciones crónicas debe ser prioritaria.

Enfermedad crónica; obesidad; consumo de bebidas alcohólicas; pobreza; tabaquismo; Nicaragua. 